\title{
Correlation between prostate-specific antigen and bone scan findings in patients with prostate cancer at Grey's Hospital, KwaZulu-Natal: A retrospective chart review
}

\begin{tabular}{|c|c|}
\hline \multicolumn{2}{|c|}{$\begin{array}{l}\text { Authors: } \\
\text { Farag Omar } \\
\text { Omran El-Koha } \\
\text { Wilbert Sibanda }^{1}\end{array}$} \\
\hline \multicolumn{2}{|c|}{$\begin{array}{l}\text { Affiliations: } \\
{ }^{1} \text { Department of Radiotherapy } \\
\text { and Oncology, University of } \\
\text { KwaZulu-Natal, Durban, } \\
\text { South Africa }\end{array}$} \\
\hline \multicolumn{2}{|c|}{$\begin{array}{l}{ }^{2} \text { School of Mathematics, } \\
\text { Statistics and Computer } \\
\text { Science, University of } \\
\text { KwaZulu-Natal, Durban, } \\
\text { South Africa }\end{array}$} \\
\hline \multicolumn{2}{|c|}{$\begin{array}{l}\text { Corresponding author: } \\
\text { Farag Omar, } \\
\text { faranor16@gmail.com }\end{array}$} \\
\hline \multicolumn{2}{|c|}{$\begin{array}{l}\text { Dates: } \\
\text { Received: } 04 \text { Sept. } 2019 \\
\text { Accepted: } 01 \text { Oct. } 2019 \\
\text { Published: } 30 \text { Jan. } 2020\end{array}$} \\
\hline \multicolumn{2}{|c|}{$\begin{array}{l}\text { How to cite this article: } \\
\text { Omar F, El-Koha O, Sibanda W } \\
\text { Correlation between } \\
\text { prostate-specific antigen and } \\
\text { bone scan findings in patients } \\
\text { with prostate cancer at Grey's } \\
\text { Hospital, KwaZulu-Natal: A } \\
\text { retrospective chart review. } \\
\text { S. Afr. j. oncol. 2020;4(0), } \\
\text { a100. https://doi.org/ } \\
\text { 10.4102/sajo.v4i0.100 }\end{array}$} \\
\hline \multicolumn{2}{|c|}{$\begin{array}{l}\text { Copyright: } \\
\text { C 2020. The Authors } \\
\text { Licensee: AOSIS. This } \\
\text { is licensed under the } \\
\text { Creative Commons } \\
\text { Attribution License. }\end{array}$} \\
\hline \multicolumn{2}{|l|}{ Read online: } \\
\hline 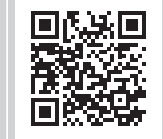 & $\begin{array}{l}\text { Scan this QR } \\
\text { code with your } \\
\text { smart phone or } \\
\text { mobile device } \\
\text { to read online. }\end{array}$ \\
\hline
\end{tabular}

Many studies have indicated that prostate-specific antigen (PSA) is used for the detection and monitoring of prostate cancer. We analysed PSA levels and bone scan findings to determine whether PSA can accurately predict bone metastases. A study was conducted at Grey's Hospital, a public hospital in Pietermaritzburg, KwaZulu-Natal, South Africa. A total of 84 patients were included in this study: 61 (72.62\%) black patients, 14 (16.67\%) Indian and $9(10.71 \%)$ white patients. Our study indicated a high correlation between PSA level and bone scan finding. We arrived at a conclusion that at PSA level $>24 \mathrm{ng} / \mathrm{mL}$, bone scan is highly recommended.

Keywords: PSA; bone scan; prostate; cancer correlation; Grey's Hospital.

\section{Introduction}

Prostate-specific antigen (PSA) is widely used in the detection and monitoring of prostate cancer. ${ }^{1,2}$ Prostate-specific antigen is a glycoprotein produced by the epithelial cells of both normal and cancerous prostatic tissues, and is a vital tool for staging prostate carcinoma prior to treatment. ${ }^{3}$ Bone scans are regarded as important images in the pre-treatment of the patients. Many studies have shown a significant correlation between serum PSA levels and prostate cancer. ${ }^{4}$ In general, bone scans are expensive and time-consuming ${ }^{5}$ compared to PSA. In this study, we aim to determine if there is a high correlation between PSA test and bone scan findings.

\section{Research methods and design Patient population}

In this retrospective study, 84 patients were selected from patient files over a period of 3 years, between 2015 and 2018. Bone scans were read as either positive or negative for metastases, based on radionuclide uptake. Serum PSA assays were performed using immunoradiometric assay (IRMA). The normal range in this laboratory is $0 \mathrm{ng} / \mathrm{mL}-4 \mathrm{ng} / \mathrm{mL}$.

\section{Statistical methods}

Data analysis was performed using IBM SPSS version 25 (Armonk, NY, USA) and Statistical Analysis Software (SAS) version 9.0 (SAS Institute, Cary, NC). Continuous variables were summarised using mean \pm standard deviation (SD), and medians and interquartile ranges (IQR) were used for highly skewed data. Categorical variables were summarised using proportions and percentages. Proportions and categorical variables were compared using Pearson's chi-square test and Fisher's exact test as appropriate.

\section{Ethical considerations}

Ethical approval was obtained from Biomedical Research Ethics Committee (BREC) of the University of KwaZulu-Natal (BREC number BE295/18).

\section{Results}

A total of 84 patients were included in this study: 61 (72.62\%) black patients, $14(16.67 \%)$ Indian patients and $9(10.71 \%)$ white patients. The age range of patients was from 51 to 82 years, 
with the following mean ages for different ethnic groups: black patients, $68.63 \pm 6.40$ years; Indian patients, $68.28 \pm 6.56$ years and white patients, $70.47 \pm 5.61$ years. Using, a ShapiroWilk's test for normality, age of patients was found to be nonnormally distributed, $p=0.056$. The median ages of black, Indian and white patients were 69 (IQR 63-75), 66 (IQR 64.75-72.5) and 64 (IQR 62.50-76.50), respectively.

Of the 84 bone scans, $36(42.86 \%)$ were positive (Table 1$)$, and all the 36 patients had elevated PSA levels $(>4.1)$, with a mean $304.81 \mathrm{ng} / \mathrm{mL} \pm 156 \mathrm{ng} / \mathrm{mL}$ and median $55.0 \mathrm{ng} / \mathrm{mL}$. Table 1 summarises the results of this study, with respect to race, age and PSA. Prostate-specific antigen and race had a statistically significant association with the incidence of a positive bone scan, with $p$-values of 0.012 and 0.000 , respectively. Of significance is the fact that 24 patients $(92.31 \%)$ out of 26 patients with PSA $\geq 100$ had positive bone scan.

No patient with serum PSA value in the reference range $(0.0 \mathrm{ng} / \mathrm{mL}-4.0 \mathrm{ng} / \mathrm{mL})$ had a positive bone scan. As shown in Table 1, patients represented a wide range of ages and PSA values. Using a Fisher's exact test, no statistically significant association between patient age and incidence of bone metastases was observed, $p=0.10$. However, bone metastases had a statistically significant association with patients' race, PSA level and risk level, with $p$-values of 0.012, 0.000 and 0.000 , respectively. The mean and median serum PSA concentrations in patients with a positive bone scan were $560.54 \mathrm{ng} / \mathrm{mL} \pm 890.93 \mathrm{ng} / \mathrm{mL}$ and 196.50 (IQR 56-802), whereas patients with a negative bone scan had a mean and median serum PSA level of $38.27 \mathrm{ng} / \mathrm{mL} \pm 69.45 \mathrm{ng} / \mathrm{mL}$ and 20 (IQR 9-40.7) ng/mL, respectively. Using an unpaired

TABLE 1: Correlation of age and prostate-specific antigen (PSA) with bone scan findings.

\begin{tabular}{|c|c|c|c|c|}
\hline \multirow[t]{2}{*}{ Variable } & \multicolumn{2}{|c|}{ No. of patients } & \multicolumn{2}{|c|}{$\begin{array}{l}\text { No. of patients with } \\
\text { positive bone scan }\end{array}$} \\
\hline & $n$ & $\%$ & $n$ & $\%$ \\
\hline \multicolumn{5}{|l|}{ Race } \\
\hline Black people & 61 & 72.62 & 31 & 50.82 \\
\hline White people & 9 & 7.14 & 4 & 44.44 \\
\hline Indian people & 14 & 16.67 & 1 & 7.14 \\
\hline Total & 84 & 100.00 & 36 & 42.86 \\
\hline \multicolumn{5}{|l|}{ Age (years) } \\
\hline $50-59$ & 6 & 7.14 & 4 & 66.67 \\
\hline $60-69$ & 41 & 48.81 & 13 & 31.71 \\
\hline$\geq 70$ & 37 & 44.05 & 19 & 51.35 \\
\hline Total & 84 & 100.00 & 36 & 42.86 \\
\hline \multicolumn{5}{|l|}{ PSA (ng/mL) } \\
\hline $0.0-4.0$ & 1 & 1.19 & 0 & 0.00 \\
\hline $4.1-10.0$ & 12 & 14.29 & 1 & 8.33 \\
\hline $10.1-20.0$ & 12 & 14.29 & 0 & 0.00 \\
\hline $20.1-50.0$ & 21 & 25.00 & 6 & 28.57 \\
\hline 50.1-100.00 & 12 & 14.29 & 5 & 41.67 \\
\hline$\geq 100$ & 26 & 30.95 & 24 & 92.31 \\
\hline Total & 84 & 100.00 & 36 & 42.86 \\
\hline \multicolumn{5}{|l|}{ Risk factor } \\
\hline Low risk & 4 & 4.76 & 0 & 0.00 \\
\hline Intermediate risk & 18 & 21.43 & 0 & 0.00 \\
\hline High risk & 26 & 30.95 & 0 & 0.00 \\
\hline Metastatic & 36 & 42.86 & 36 & 100.00 \\
\hline Total & 84 & 100 & 36 & 100.00 \\
\hline
\end{tabular}

$t$-test, the difference in the mean serum PSA levels between patients with a positive bone scan and those without it was statistically significant, $p=0.0001$. Only one patient $(1.19 \%)$ had a serum PSA value in the reference range $(0.0 \mathrm{ng} / \mathrm{mL}-4.0 \mathrm{ng} / \mathrm{mL})$, and the patient had a negative bone scan, indicating no evidence of bone metastases.

\section{Discussion}

The incidence rate of prostate cancer in Africa is highly variable, ranging from 10.6 per 100000 in Northern Africa to 61.8 per 100000 in Southern Africa. ${ }^{6}$ A study conducted by Ferlay et al. ${ }^{7}$ indicated that the incidence of prostate cancer in South Africa in 2012 was 67.9 per 100000 . Our study indicated a high correlation between PSA level and the frequency of positive bone scan findings.

Based on the high correlation between PSA and bone scan findings, we highly recommend that at PSA level $>24 \mathrm{ng} / \mathrm{mL}$, bone scan should be performed as PSA level of $24 \mathrm{ng} / \mathrm{mL}$ indicates a $63 \%$ positive bone scan. Numerous studies around the world indicate that PSA $>20 \mathrm{ng} / \mathrm{mL}$ is more accurate in predicting metastasis on bone scan. However, the shortcoming in our study was the small sample size. Therefore, a future study with more subjects can shed more light on the correlation between PSA levels and bone scans findings.

\section{Conclusion}

Our study indicated a high correlation between PSA level and the number of positive bone scan findings. However, the shortcoming of this study was the small sample size. Further multi-institutional studies with larger samples are recommended to validate our findings.

\section{Acknowledgements}

The authors would like to acknowledge all the assistance from the Department of Oncology and Radiotherapy, Grey's Hospital in conducting this study.

\section{Competing interests}

The authors declare that they have no financial or personal relationships that may have inappropriately influenced them in writing this article.

\section{Authors' contributions}

All authors contributed equally to this work.

\section{Funding information}

This research received no specific grant from any funding agency in the public, commercial or not-for-profit sectors.

\section{Data availability statement}

Data sharing is not applicable to this article as no new data were created or analysed in this study. 


\section{Disclaimer}

The views and opinions expressed in this article are those of the authors and do not necessarily reflect the official policy or position of any affiliated agency of the authors.

\section{References}

1. Grzeda BR, Le Bui T, Warner CN, et al. Measurement of prostate-specific antigen by use of a novel blood collection and analytical system. Clin Chem. 2002;48(8):1272-1278.

2. Stamey TA, Kabalin JN, McNeal JE, et al. Prostate specific antigen in the diagnosis and treatment of adenocarcinoma of the prostate: II. Radical prostatectomy treated patients. Urology. 1989;141(15):1076-1083. https://doi.org/10.1016/ treated patients. Urology.
3. Stamey TA, Yang N, Hay AR, et al. Prostate-specific antigen as a serum marker for adenocarcinoma of the prostate. N Engl J Med. 1987;317(15):909-916. https:// doi.org/10.1056/NEJM198710083171501

4. Catalona WJ, Smith DS, Ratliff TL, et al. Measurement of prostate-specific antigen in serum as a screening test for prostate cancer. N Engl J Med. 1991; 324(17):1156-1161. https://doi.org/10.1056/NEJM199104253241702

5. Hirobe M, Takahashi A, Hisasue S-I, et al. Bone scanning - Who needs it among patients with newly diagnosed prostate cancer? Jpn J Clin Oncol. 2007; 37(10):788-792. https://doi.org/10.1093/jjco/hym097

6. Le Roux HA, Urry RJ, Sartorius B, Aldous C. Prostate cancer at a regional hospital in South Africa: We are only seeing the tip of the iceberg. S Afr J Surg. 2015; 53(4):57-62.

7. Ferlay J, Soerjomataram I, Ervik M, et al. GLOBOCAN 2012 v1.0, Cancer incidence and mortality worldwide: IARC Cancer Base No. 11 [homepage on the Internet]. Lyon: International Agency for Research on Cancer; 2013 [cited 2014 Oct 14]. Available from: http://globocan.iarc.fr 